\title{
接合部詳細の違いに着目した 2 層 1 スパン実大ブレース架構の実験 \\ EXPERIMENTAL STUDY ON 2 STORY-1 BAY FULL-SCALE BRACED FRAME FOCUSING ON THE DIFFERENCE OF CONNECTION DETAIL
}

\author{
巽信彦*, 吉敷祥一**, 長谷川 隆***, 山田 哲**** \\ Nobuhiko TATSUMI, Shoichi KISHIKI, Takashi HASEGAWA \\ and Satoshi YAMADA
}

\begin{abstract}
Beam-to-column connections in the braced frames are assumed as pin connections in seismic design, and seismic performance of the braced frames depends on the strength of the brace. However, the effects of various differences in connection details on the seismic performance of the braced frames are unclear. The aspects are investigated in the present paper, and their effects on the structural behavior are described. Cyclic loading tests of 2 story-1 bay full-scale braced frames with various connections were carried out in order to investigate the effect of connection eccentricity of brace and details of the beam-end connection. The test results indicate that the connection eccentricity of brace decreases the maximum strength and elastic stiffness of the braced frame.
\end{abstract}

Keywords : full-scale test, braced frame, connection detail, connection eccentricity of brace, ultimate horizontal strength 実大実験, ブレース構造, 接合部詳細, ブレースの偏心, 終局耐力

\section{1. はじめに}

災害時に防災拠点としての機能が期待される屋内運動場などは, 高い耐震性能が要求される建物であり, 広い空間を有する低層の鉄 骨造で構成される.この種の建物は柱にH形断面材を用い, 桁行き 方向は柱を弱軸使いとし，梁との接合部を構造計算上ピンとして 扱った純ブレース構造とすることが多く,その耐震性能はブレース の軸部降伏を保証することにより確保される.ブレースの保有性能

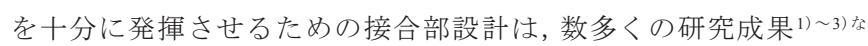
どにより構築され, その効果は近年の地震被害調査において実証さ れつつある4)なと. 一方, このブレース端の接合部は, 地震力を負担 しないと考える同一構面の柱と梁の接合部, さらに構面直交方向の 梁の接合部を兼祇る場合もあるために立体的に複雑な形状となり, 現状では工場製作や現場での施工性を優先としたディテールが採用 されることが多い.これは, 柱梁との接合部分を含めた架構として の実験(5) 8)など少なく, 接合部詳細の違いが架構全体の力学挙動に 及ぼす影響が明らかでないことが遠因となっていると考える.例え ば柱と梁の部材断面, 柱梁部材心交点に対するブレースの偏心, ピ ンとして扱う梁端接合部における曲げ負担などが架構全体の力学挙 動に及ぼす影響を定量的に評価できれば, 高い耐震性能を確保する ための接合部詳細を合理的に決定できる可能性がある.
著者らはこれまでに接合部詳細の違いに着目したブレース付き $\mathrm{L}$ 字形部分架構の実験 ${ }^{8)}$ を行い, 片持ち梁状のガセットプレートの最 大耐力やブレースの偏心による影響を検討したが, 柱梁の反曲点位 置を固定していたため, より現実的な条件下での検討が課題として 残されていた。本研究では2層1スパンの実大ブレース架構を試験 体として用意し, 主としてブレースの偏心や梁端接合部の違いに着 目した構造実験を行い, 接合部詳細の違いが架構全体の力学挙動に 及ぼす影響を把握する.また, それらの実験結果から架構全体の剛 性と耐力に及ぼす各構成部材の影響を評価する。

\section{2. 実験計画}

\section{1 試験体の概要}

試験体概要を図 1 に示す。試験体は，柱，梁，ブレースからなる スパン $4.0 \mathrm{~m}$, 階高 $2.5 \mathrm{~m}$ の 2 層 1 スパン実大ブレース架構である. 試 験体の柱と梁はH形鋼をそれぞれ弱軸使いと強軸使いで用い, 柱に は梁とブレースを接合するためのガセットプレート(PL9)を両面隅 肉溶接にて取り付けている. 梁端接合部は, 梁ウェブを 3 本の高力 ボルトで摩擦接合するピンディテールである.なお,端あき距離は $40 \mathrm{~mm}$ とし, 梁フランジの端部にはガセットプレートとの干涉を避 けるための切り欠きを施している.ブレースは等辺山形鋼あるいは
* 日本学術振興会特別研究員 ·修士(工学) (大阪工業大学大学院 博士後期課程)

** 東京工業大学科学技術創成研究院未来産業技術研究所 准教授. 博士 (工学)

*** 建築研究所構造研究グループ 主任研究員・博士 (工学

**** 東京工業大学科学技術創成研究院未来産業技術研究所 教授・博士 (工学)
JSPS Research Fellow, M.Eng.

(Grad. Stud., Osaka Institute of Technology)

Assoc. Prof., F.I.R.S.T., Tokyo Institute of Technology, Dr.Eng.

Senior Researcher, Structural Engineering Dept., Building Research Institute, Dr.Eng.

Prof., F.I.R.S.T., Tokyo Institute of Technology, Dr.Eng. 


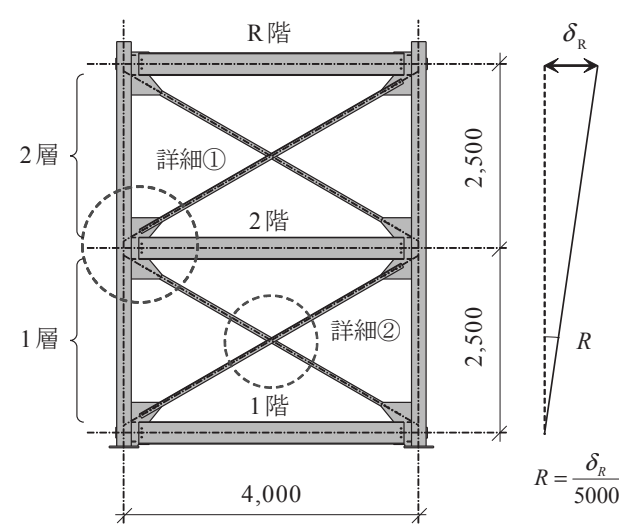

図1試験体の概要

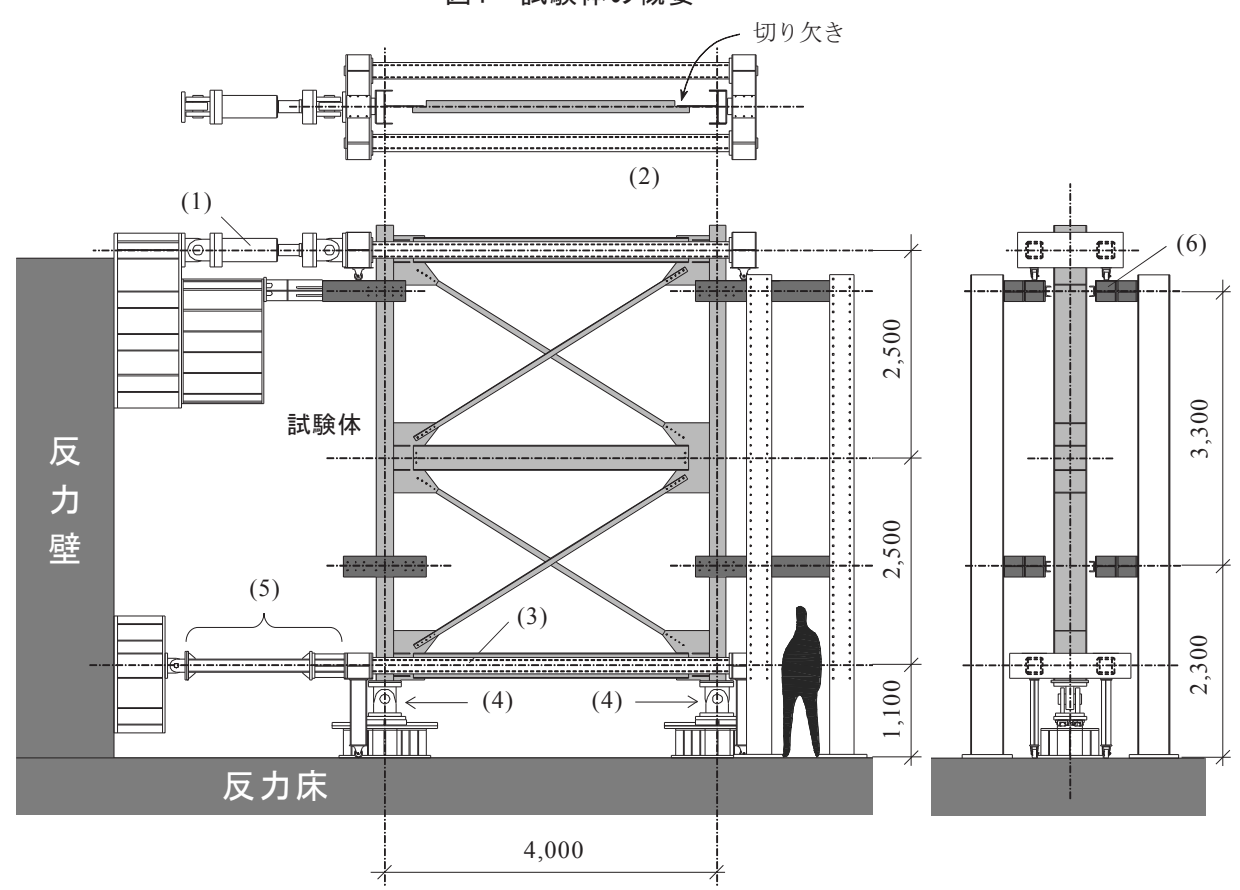

(1): $1000 \mathrm{kN}$ 油圧ジャッキ (2): 加力梁 (2x $\square-200 \times 200 \times 9)$

(3): 反力梁 $(2 \times \square-200 \times 200 \times 9)$
(4): ピンローラー治具
(5): 水平反力治具 $(2 \times \square-150 \times 150 \times 6)$
(6): 横補剛

図2 セットアップ

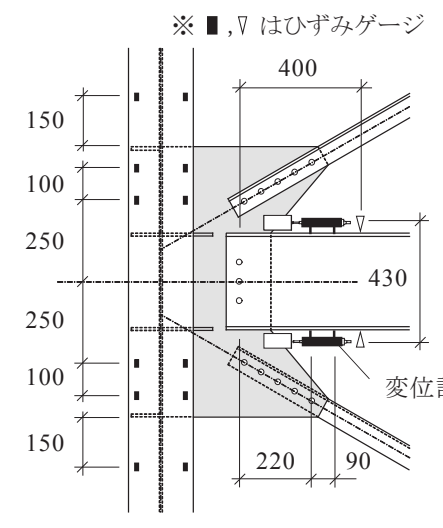

図4 計測計画

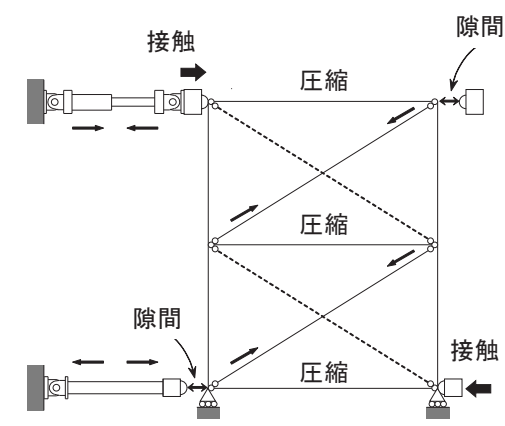

（a）正載荷時

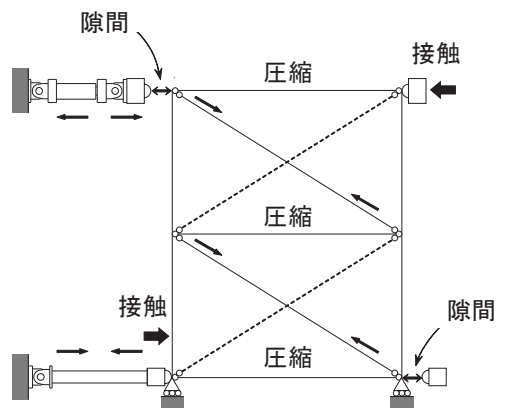

（b）負載荷時

図3 載荷方法の概要
平鋼をX形に配し,一部の試験体ではブレースの交差部にガセット プレート (以後, 中間ガセット)を設ける.なお, 中間ガセットを設 ける場合には負載荷時に引張となるブレースを中間ガセットで2分 割する.ブレース端接合部は, M16 (F10T)の高力ボルト5本を標準 ボルトピッチ $(60 \mathrm{~mm})$, 端あき距離 $40 \mathrm{~mm}$ にて配置し, 保有耐力接 合9の条件を満たしている.

\section{2 載荷装置}

セットアップを図 2 に, 載荷方法の概要を図 3 に示す. 試験体は 柱脚下部を水平方向に自由なピンローラー治具を介して反力床に固 定し，さらにR 階，1階の梁は左右に隙間を設けて加力梁，反力梁 に接続する. 加力梁と反力梁は試験体を囲う口字形とし, その下部 を水平方向に自由なローラーで支持するとともに, 両端ピンの油圧 ジャッキと水平反力治具によって反力壁に固定する.油圧ジャッキ の荷重は, 加力梁を介して試験体に伝達され, その後に反力梁, 水 平反力治具を介して反力壁に伝達される (図 3). 一方, 鉛直方向の 反力は柱脚部のピンローラー治具によって確保する. 試験体と加力
梁, および試験体と反力梁の間には隙間を設けたため, 水平力は接 触によって試験体に伝達され, 正負載荷時ともにすべての階の梁に ほぼ同等の圧縮軸力が作用する状況を実現し, 圧縮軸力下における 梁端接合部の挙動を把握する。

載荷は，平均層間変形角 $R$ によって制御して行い， $\pm 1 / 200 ， \pm$ $1 / 100 ， \pm 1 / 50 ， \pm 1 / 33 \mathrm{rad}$. の各振幅をそれぞれ 2 サイクルずつ繰 り返す, 正負交番漸増変位振幅載荷を行った。ここで, 平均層間変 形角 $R$ は, $\mathrm{R}$ 階梁と 1 階梁の相対水平変形を 2 層分の階高で除して 求める. なお, 相対水平変形は柱脚部の鉛直変位による回転, およ び加力梁, 反力梁と試験体の相対変位を除去して得ている.

\section{3 計測計画}

実験では層せん断力 $Q$ を油圧ジャッキに組み込んだロードセルで 計測するとともに, 制御に用いる平均層間変形角 $R$ を算出する変位 計を配置している.これらに加え, 各接合部において図4に示寸計 測を行った. 接合部の変位計は, 梁端接合部 (高力ボルト位置) から 220〜310mm離れた位置の上下フランジを基点として取り付け, ガ 
表 1 試験体一覧

\begin{tabular}{|c|c|c|c|c|c|c|c|c|c|c|c|}
\hline \multirow[b]{2}{*}{ 試験体 } & \multirow[b]{2}{*}{ 柱断面 } & \multirow[b]{2}{*}{ 梁断面 } & \multirow[b]{2}{*}{ ブレース断面 } & \multicolumn{2}{|c|}{ ブレースの使用鋼材 } & \multirow{2}{*}{$\begin{array}{c}\text { 中間ガセット } \\
\text { の有無 }\end{array}$} & \multirow{2}{*}{$\begin{array}{c}\text { 梁端 } \\
\text { ボルトピッチ } \\
p[\mathrm{~mm}]\end{array}$} & \multirow{2}{*}{$\begin{array}{c}\text { 梁端 } \\
\text { ボルト径 }\end{array}$} & \multirow{2}{*}{$\begin{array}{c}\text { ブレース } \\
\text { 偏心距離 } \\
e[\mathrm{~mm}]\end{array}$} & \multicolumn{2}{|c|}{ 引張側ブレースに基づく } \\
\hline & & & & ロット & $\begin{array}{c}\text { 降伏点 } \\
\sigma_{\mathrm{y}}\left[\mathrm{N} / \mathrm{mm}^{2}\right] \\
\end{array}$ & & & & & $\begin{array}{c}\text { 水平剛性 } \\
{ }_{\mathrm{b}} K[\mathrm{kN} / \mathrm{rad} \text {. }]\end{array}$ & $\begin{array}{l}\text { 水平耐力 } \\
{ }_{\mathrm{b}} Q_{\mathrm{y}}[\mathrm{kN}]\end{array}$ \\
\hline Le- 0 & \multirow{4}{*}{ RH-400x200x8x13 } & \multirow{10}{*}{ RH-300x150x6.5x9 } & \multirow{9}{*}{ L- $65 \times 65 \times 6$} & \multirow{4}{*}{ I } & \multirow{4}{*}{323} & \multirow{4}{*}{ なし } & \multirow{4}{*}{60} & \multirow{4}{*}{ M16 } & 0 & 58800 & 206 \\
\hline Le-100 & & & & & & & & & 100 & 62800 & 211 \\
\hline Le-200 & & & & & & & & & 200 & 66900 & 215 \\
\hline Le-300 & & & & & & & & & 300 & 71100 & 220 \\
\hline Se- 0 & \multirow{4}{*}{ BH-285x170x6x6 } & & & \multirow{4}{*}{ II } & \multirow{4}{*}{320} & \multirow{4}{*}{ あり } & \multirow{4}{*}{80} & \multirow{4}{*}{ M20 } & 0 & 58800 & 204 \\
\hline Se-100 & & & & & & & & & 100 & 62800 & 209 \\
\hline Se-200 & & & & & & & & & 200 & 66900 & 213 \\
\hline Se-300 & & & & & & & & & 300 & 71100 & 218 \\
\hline Lp- 40 & \multirow{2}{*}{ RH-400x200x8x13 } & & & $\mathrm{I}$ & 323 & なし & 40 & \multirow{2}{*}{$\mathrm{N}$} & \multirow{2}{*}{0} & 58800 & 206 \\
\hline Lp- 80 & & & FB-80x16 & III & 287 & あり & 80 & & & 100000 & 312 \\
\hline
\end{tabular}

セットプレートまでの相対変形を計測することで梁端接合部の回転 変形 ${ }_{\mathrm{b}} \theta$ を算出する. また梁端接合部から $400 \mathrm{~mm}$ 離れた位置の断面 にひずみゲージを貼付し, 梁に作用する軸方向力, せん断力を算出 し, さらに梁端接合部に作用寸る曲げモーメント ${ }_{\mathrm{b}} M$ を得る.一方, 柱については, ガセットプレートの縁端から $150 \mathrm{~mm}$ 離れた位置の 断面にひずみゲージを貼付し, 梁と同様に柱に作用する軸方向力, せん断力を算出する.さらにガセットプレートが取り付く断面を含 め, 柱の曲げモーメント分布を得る.

\section{4 試験体と実験パラメータ}

実験パラメータの定義を図 1 の詳細(1)，(2)に示す. 実験パラメー タは梁端接合部のボルトピッチ $p$ とボルト径, ブレースの偏心距離 $e$, 柱断面, ブレース断面, 中間ガセットの有無である.ここで, ボ ルトピッチ $p$ は, 梁せい方向のボルト間距離である.また, ブレー スの偏心距離 $e$ は柱梁部材心交点からブレースと柱の部材心交点ま での距離とする.試験体は, 梁端接合部の高力ボルトをM16(F10T) として標準ボルトピッチ $(60 \mathrm{~mm})$ で配置したブレースの偏心がない Le- 0 を基準とし，ブレースの偏心距離と柱断面を変化させた 8 体 (Le, Seシリーズ) と, 梁端接合部のボルトピッチとブレース断面を 変化させた 2 体 (Lp シリーズ)の計 10 体を用意した。このうち, Se シリーズでは柱に幅厚比の大きな断面を用いており, フランジと ウェブの幅厚比はそれぞれ 14.2, 45.5である. 試験体一覧を表 1 に 示す.表中には素材試験にて得られたブレースの降伏点を併せて示 している.また, 引張側ブレースのみを考え, 節点間距離を材長と したブレースの軸剛性に基づく水平剛性 ${ }_{\mathrm{b}} K$, および公称断面と素 材試験結果を用いたブレースの軸部降伏耐力時の水平耐力 ${ }_{\mathrm{b}} Q_{\mathrm{y}}$ (以 後, 軸部降伏時の水平耐力)の計算值も示している.

Leシリーズの接合部詳細を図5に例示する.全試験体の接合部詳 細に関する共通のルールとして, ガセットプレートの形状は, ブ レースの基線に対する梁側への拡がりを $20^{\circ}$ とし,ガセットプレー トの有効断面を確保するように決定した.また, ブレースの端部は, ブレースの座屈に伴う面外変形や梁端接合部の回転変形によって梁 フランジと接触しないよう, $50 \mathrm{~mm}$ 以上のクリアランスを設けるこ ととした.さらに, 柱には, 応力伝達を円滑にするためにガセット プレートの縁端と梁フランジ位置に水平スチフナを取り付けた.

\section{5 部材耐力と接合部耐力}

次いで, 試験体に使用する柱と梁の部材耐力, 梁端接合部の耐力 を表 2 に示す. 部材耐力の計算には, 鋼材の基準強度 $F$ 値 ${ }^{10)}$ を用い,
高力ボルトのすべり耐力と破断耐力には, それぞれ短期許容せん断 力 ${ }^{10)}$ と最大せん断耐力 ${ }^{11)}$ を用いている. 表中の曲げすべり耐力は, 梁端接合部の高力ボルトのうち, 上下の 2 本がす心゙り耐力を発揮し たときの曲げ耐力である.また, 軸方向す心゙り耐力と軸方向破断耐 力は, それぞれ高力ボルト3本の寸べり耐力, 破断耐力の和である. 梁端接合部の曲げすべり耐力は,いずれも梁の降伏モーメントの約 $3 \sim 10 \%$ と小さことが分かる.

ここで, 梁端接合部の軸方向力に対する性能を図 6 に示す. 縦軸 は梁に作用する軸方向力 $N$ であり, 横軸は梁端接合部のボルト径で ある. 図中には軸部降伏時の水平耐力 ${ }_{\mathrm{b}} Q_{\mathrm{y}}$ を破線にて示している. 軸方向すべり耐力は。 $Q_{\mathrm{y}}$ 以下であり, 実験中に梁端接合部の高力ボ ルト接合部にす心゙りが生じると予想される.一方, 軸方向破断耐力 は ${ }_{\mathrm{b}} \mathrm{y}_{\mathrm{y}}$ の $1.2 \sim 2.8$ 倍の範囲にあり，梁端接合部はいずれも軸方向 力に対しては保有耐力接合9)条件を満たしていると考えられる.

\section{3. 実験結果と考察}

\section{1 全体挙動と実験結果の概要}

実験より得られた全体挙動として層せん断力ー平均層間変形角関 係を図 7 図 9 に, 実験結果の一覧を表 3 に示寸. 図の縦軸は層せ 几断力 $Q$ であり, 横軸は平均層間変形角 $R$ である。図中の破線は ブレースの偏心がない Le- 0 と Se-0の軸部降伏時の水平耐力 ${ }_{\mathrm{b}} Q_{\mathrm{y}}$ で あり, 太実線は履歴挙動の包絡線である。また, 表中の弾性剛性は 土1/200rad.サイクルにおける除荷剛性とした.

いずれの試験体も $\pm 1 / 200 \mathrm{rad}$. サイクルではほぼ弾性範囲に留 まっており, 高い剛性を維持している.ブレースの偏心がない試験 体における水平剛性は, 節点間距離を材長とした引張側ブレースの 軸剛性に基づく計算值 (表 1 ) とほぼ一致する.続く $\pm 1 / 100 \mathrm{rad}$.サイ クルでは, 引張側ブレースが軸部降伏に至り, 軸部降伏時の水平耐 力 ${ }_{\mathrm{b}} Q_{\mathrm{y}}$ を上回る最大耐力を発揮し, その後はほぼ一定の耐力を維持 している.繰り返し変形に対してはスリップ挙動を呈し,同一振幅 の範囲では 2 サイクル目の耐力が低くなっている，なお，Le-0 200, Lp-40は, 載荷中に柱のねじれ変形が著しくなったため, $\pm 1 /$ 50rad.にて載荷を終了した。

Le, Seシリーズでは, ブレースの偏心距離が大きくなるほど水平 剛性，最大耐力が低下しており，偏心距離が 200,300mmの試験体 では最大耐力が軸部降伏時の水平耐力 ${ }_{\mathrm{b}} Q_{\mathrm{y}}$ を下回る結果となってい る. Leシリーズと Seシリーズを比較すると, 同じブレースの偏心 


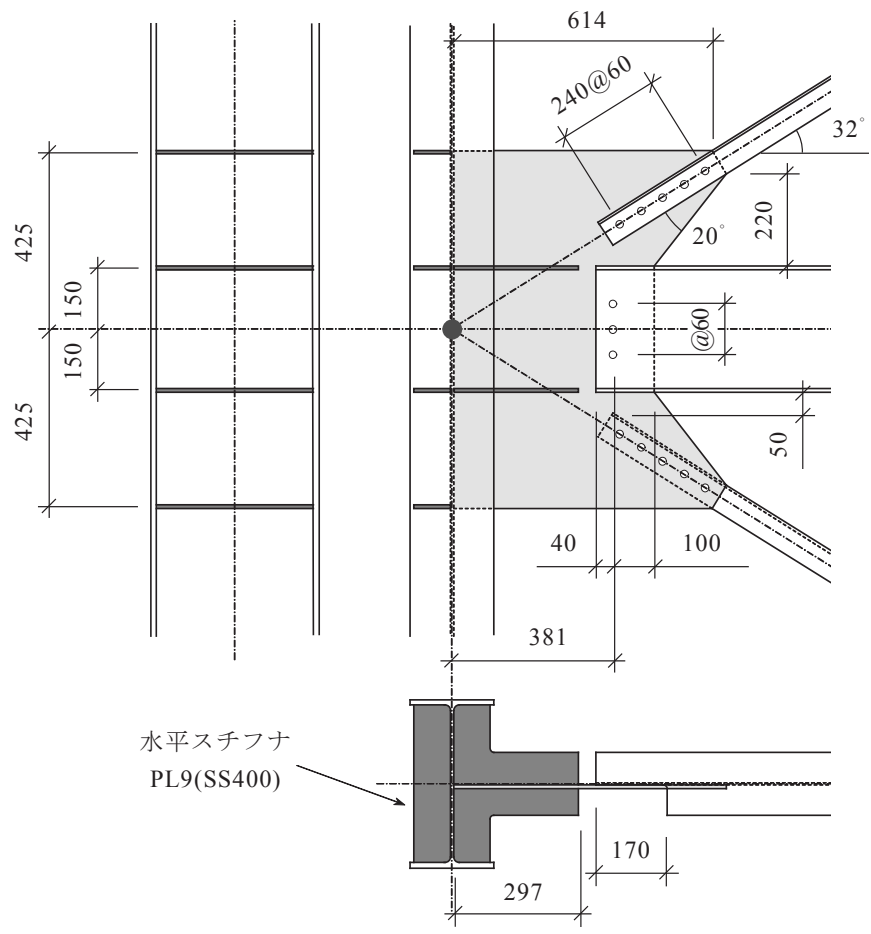

（a）基準試験体Le-0（偏心なし） 表2＼cjkstart柱梁の部材耐カー覧

\begin{tabular}{|c|c|c|c|c|}
\hline 部材 & 断面 & $\begin{array}{c}\text { 降伏モーメント } \\
M_{\mathrm{y}}[\mathrm{kN}-\mathrm{m}] \\
\end{array}$ & $\begin{array}{c}\text { 全塑性モーメント } \\
M_{\mathrm{p}}[\mathrm{kN}-\mathrm{m}] \\
\end{array}$ & $\begin{array}{c}\text { 降伏軸力 } \\
N_{\mathrm{y}}[\mathrm{kN}] \\
\end{array}$ \\
\hline \multirow{2}{*}{$\begin{array}{c}\text { 柱 } \\
\text { (弱軸) }\end{array}$} & RH-400x200x8x13 & 41 & 63 & 1925 \\
\hline & BH-285x170x6x6 & 14 & 21 & 864 \\
\hline 梁 & RH-300x150x6.5x9 & 109 & 123 & 1065 \\
\hline ボル下径 & $\begin{array}{c}\text { ボルトピッチ } \\
p[\mathrm{~mm}] \\
\end{array}$ & $\begin{array}{c}\text { 曲げすべり耐力 } \\
M_{\text {slip }}[\mathrm{kN}-\mathrm{m}] \\
\end{array}$ & \begin{tabular}{|c|} 
軸方向すべり耐力 \\
$N_{\text {slip }}[\mathrm{kN}]$ \\
\end{tabular} & $\begin{array}{c}\text { 軸方向破断耐力 } \\
N_{\mathrm{f}}[\mathrm{kN}]\end{array}$ \\
\hline \multirow{3}{*}{ M16 } & 40 & 3.6 & \multirow{3}{*}{136} & \multirow{3}{*}{363} \\
\hline & 60 & 5.4 & & \\
\hline & 80 & 7.2 & & \\
\hline M20 & 80 & 11.3 & 212 & 564 \\
\hline
\end{tabular}

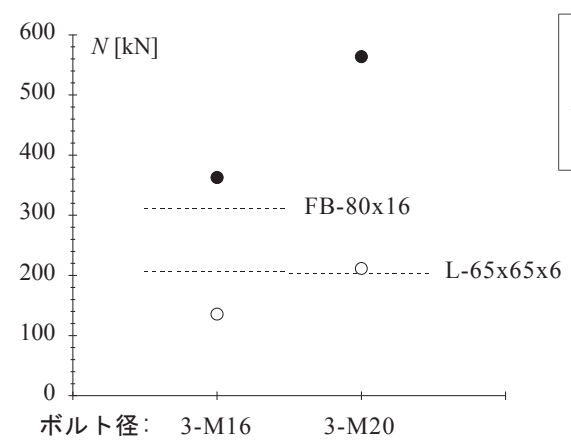

○ 破断耐力

$\bigcirc$ すべり耐力 ブレース軸部降伏 時の水平耐力

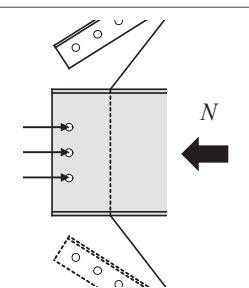

図6 梁端接合部の軸方向耐力

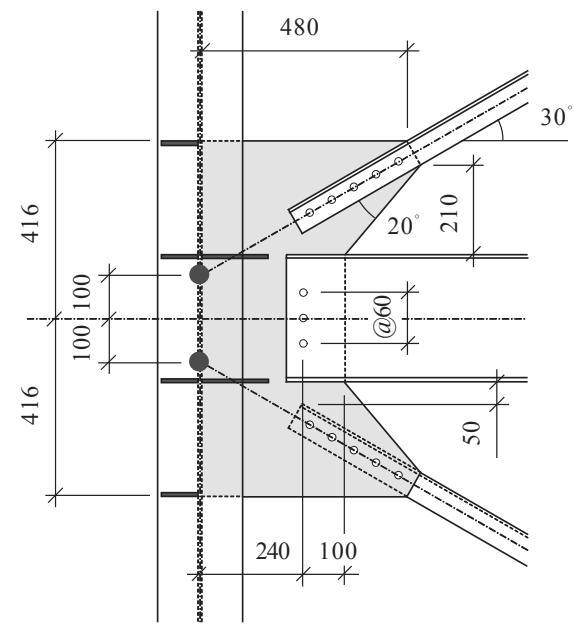

(b) 試験体 Le-100 (偏心 $100 \mathrm{~mm}$ )

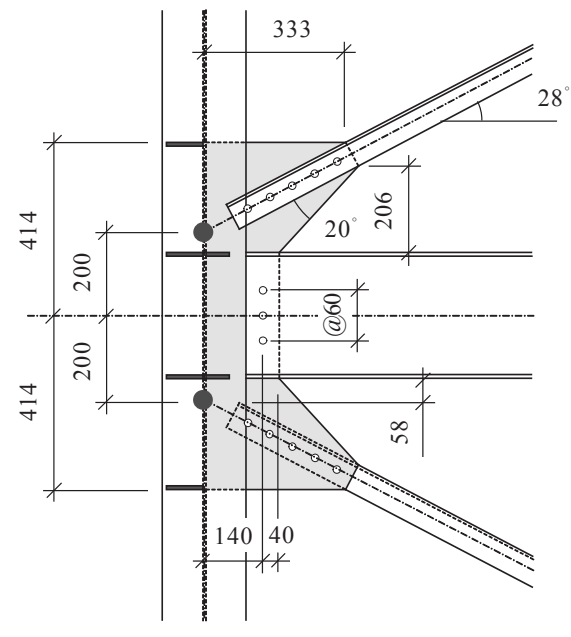

(c) 試験体 Le-200 (偏心 $200 \mathrm{~mm}$ ) 図 5 接合部詳細

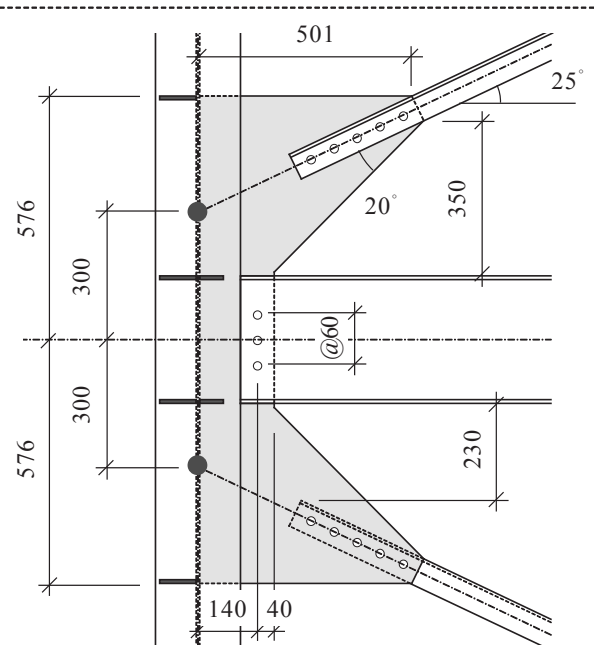

（d）試験体 Le-300(偏心 $300 \mathrm{~mm}$ )
距離であってもSeシリーズの方が全体的に耐力が高いことがわか る.これは, 梁端接合部のボルトピッチを広くとり $(60 \rightarrow 80 \mathrm{~mm})$, ボルト径を太くした $(\mathrm{M} 16 \rightarrow \mathrm{M} 20)$ ことにより柱梁架構の負担水平力 が増加したこと,さらにブレース交差部の中間ガセットの存在によ り圧縮側ブレースの負担水平力が大きくなったことが原因である. 一方, Seシリーズでは柱に幅厚比の大きな断面を用いており, ブ レースの偏心距離が大きな Se-200,Se-300 では柱に局所的な降伏 が確認されたものの, 履歴曲線はLeシリーズと類似しており, その 影響は見られない。したがって，偏心に伴う付加応力を含めてブ レースからの応力に対して柱をほぼ弾性範囲内に留められれば, 幅 厚比が大きな断面を用いても架構全体の履歴挙動には大きな影響を 及ぼさないと言える.

基準試験体 Le-0 から梁端接合部のボルトピッチをM16の 40mm
と狭くしたLp-40では, 基準試験体よりわずかに最大耐力が小さい ものの，ほぼ同様の挙動を示した。一方，基準試験体から梁端接合 部のボルトピッチを $80 \mathrm{~mm}$ と広くし,さらにブレース断面を大きく した Lp-80では， $\pm 1 / 100 \mathrm{rad}$. まではブレース端接合部のすべりを 伴いながら変形が進み, $+1 / 50 \mathrm{rad}$. で軸部降伏時の水平耐力に達して いる. その後は $-1 / 33 \mathrm{rad}$. サイクルで 1 階梁の左端の梁端接合部に おいて高力ボルトが破断し，耐力を喪失した．Lp-80の梁端接合部 はブレースの軸部降伏時に作用するであろう軸方向力に対して 1.2 倍の安全率を確保しているが, 実際には回転変形に伴う曲げ応力が 付加されたため, 曲げ圧縮側の高力ボルトが破断したものと考えら れる。したがって, 軸方向力下で回転性能を要求されるピンディ テールの梁端接合部では, 軸方向力に対寸る耐力の確保だけでな く, 回転変形に伴う付加応力も考慮した耐力の確保が必要であると 
偏心： なし

$100 \mathrm{~mm}$

$200 \mathrm{~mm}$

$300 \mathrm{~mm}$

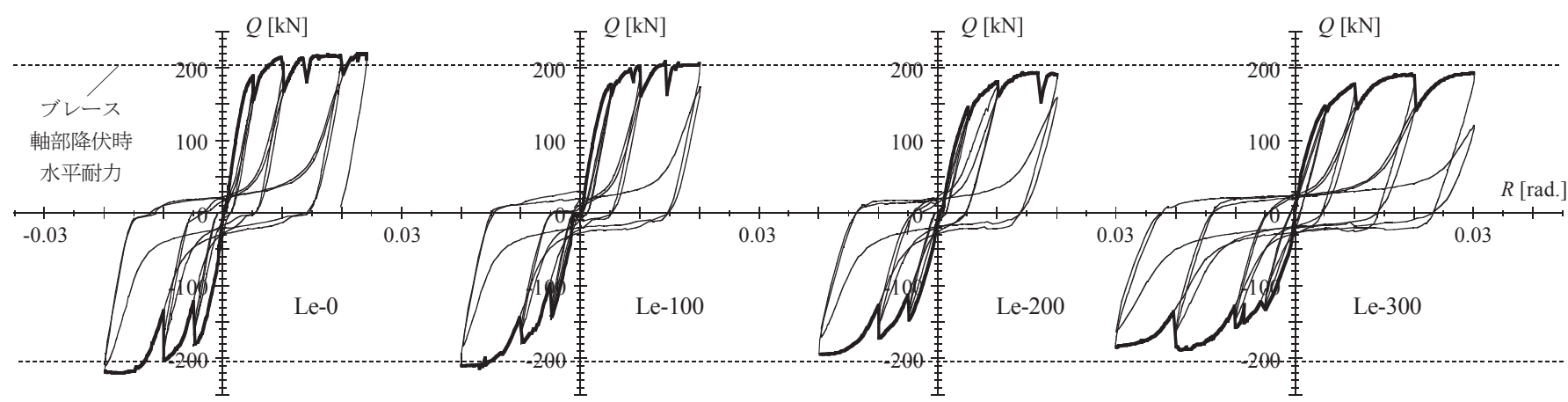

(a) 偏心なし

(b) 偏心 $100 \mathrm{~mm}$

(c) 偏心 $200 \mathrm{~mm}$

(d) 偏心 $300 \mathrm{~mm}$

図 7 Le シリーズの全体挙動

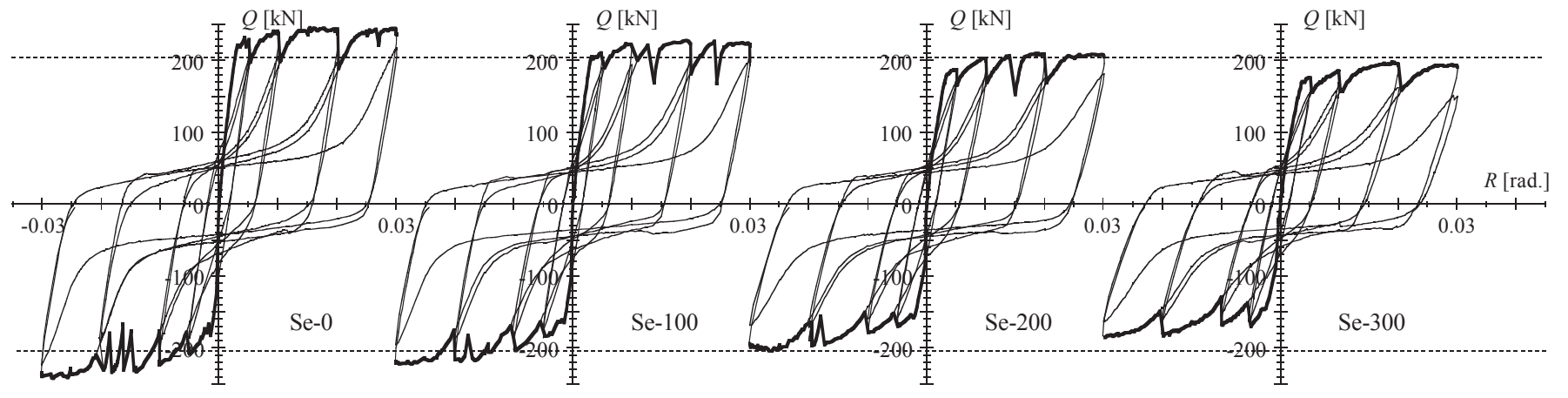

(a) 偏心なし

(b) 偏心 $100 \mathrm{~mm}$ (c) 偏心 $200 \mathrm{~mm}$ (d) 偏心 $300 \mathrm{~mm}$

図 8 Se シリーズの全体挙動

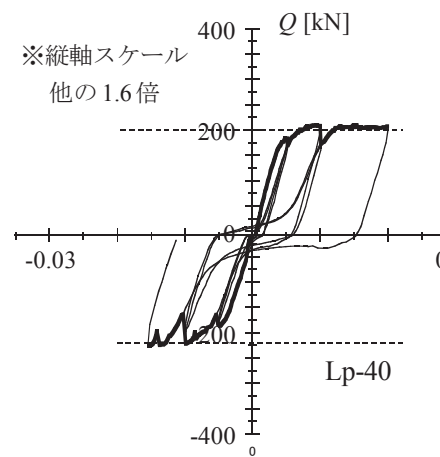

(a) ボルトピッチ $40 \mathrm{~mm}$

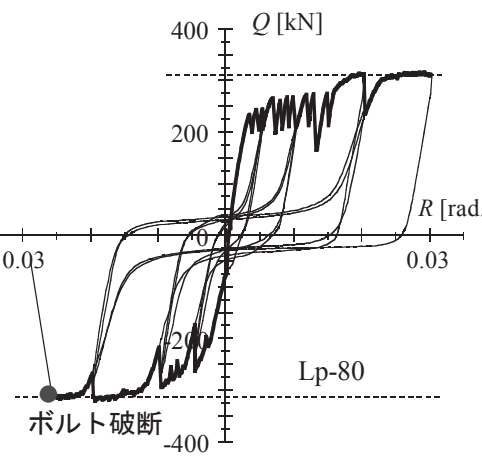

(b) ボルトピッチ $80 \mathrm{~mm}$
図 9 Lp シリーズの全体挙動

言える．また，圧縮軸力を受ける梁端ピンディテール接合部では ウェブの局部座屈により終局状態に至るケースもある12)ため, 本実 験の結果を含めたより詳細な検討については, 稿を改めて報告す る.

\section{2 ブレースの挙動 (中間ガセットの影響)}

本節以降では, 中間ガセット, 梁端接合部における曲げ負担, お よびブレースの偏心が全体挙動に及ぼす影響を考察する.ここでは まず, 中間ガセットが圧縮側ブレースの耐力に及ぼす影響について 考察する.ブレースの偏心がない試験体を対象とし, Le-0 と Se-0に おけるブレースの負担水平力を平均層間変形角 $R$ との関係として図 10 に示寸. ブレースの負担水平力 ${ }_{\mathrm{b}} Q$ は, 層せん断力から柱の負担 せん断力を減じ,さらに節点における力の釣合から引張側と圧縮側 の負担割合を梁の軸方向力に応じて定めた.

\begin{tabular}{|c|c|c|c|c|c|}
\hline \multirow{2}{*}{ 試験体 } & \multicolumn{2}{|c|}{ 最大耐力 $[\mathrm{kN}]$} & \multicolumn{2}{|c|}{ 水平剛性 $[\mathrm{kN} / \mathrm{rad}$.] } & \multirow{2}{*}{ 最終破壊形式 } \\
\hline & 正側 & 負側 & 正側 & 負側 & \\
\hline Le- 0 & 220 & -219 & 57000 & 50000 & \multirow{9}{*}{ ブレース軸部降代 } \\
\hline Le-100 & 214 & -214 & 48500 & 43000 & \\
\hline Le-200 & 194 & -194 & 39500 & 36500 & \\
\hline Le-300 & 194 & -188 & 34000 & 33000 & \\
\hline Se- 0 & 246 & -240 & 66000 & 59000 & \\
\hline Se-100 & 229 & -222 & 57500 & 50500 & \\
\hline Se-200 & 210 & -203 & 50500 & 42000 & \\
\hline Se-300 & 198 & -184 & 44000 & 40500 & \\
\hline Lp- 40 & 216 & -211 & 55500 & 45000 & \\
\hline Lp- 80 & 319 & -319 & 85000 & 82500 & 梁端ボルト破断 \\
\hline
\end{tabular}

いずれの試験体も，圧縮側では $\pm 1 / 200 \mathrm{rad}$. サイクル時に最大耐 力を発揮し, 全体座屈が生じることで急激に耐力が低下している. それ以降は引張側で新しい変形を経験する毎に圧縮側で再び全体座 屈を生じるが, 初期サイクルに比べて耐力は小さくなっている.ま た, 圧縮側の変形が進しだ領域ではほぼ一定值に耐力が漸近してい る.中間ガセットの有無を比較すると, 中間ガセットがあるSe-0で は, 中間ガセットがないLe-0に比べて圧縮側最大耐力が高く,また スリップ挙動時の履歴曲線の膨らみ(例えば変形ゼロ時点) も大きく なっていることが分かる。これは, 中間ガセットの存在によりブ レースの座屈長さが短くなったためであると考えられる.

ここで, 圧縮側最大耐力をブレースの断面積で除した最大圧縮応 力度 $\sigma_{\mathrm{cr}}$ として表し, 細長比 $\lambda$ との関係として図 11 に示寸. 図には 短期許容圧縮応力度 $f_{\mathrm{c}}{ }^{10)}$ を実線で, オイラー座屈応力度を破線にて 


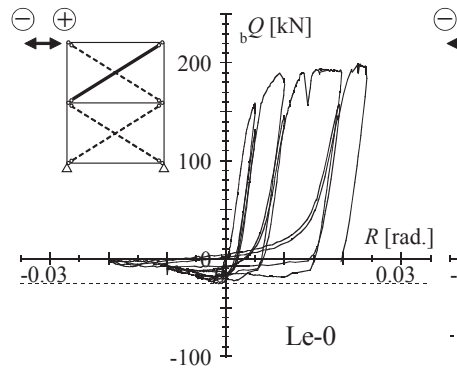

（a）先に引張を受けるブレースの負担水平カ

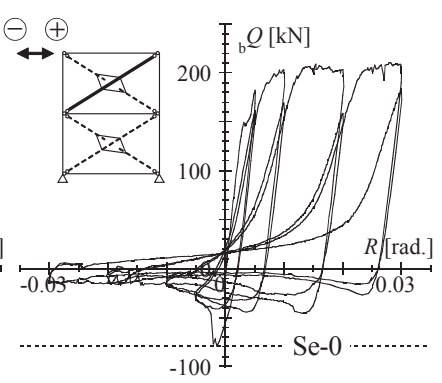

図 10
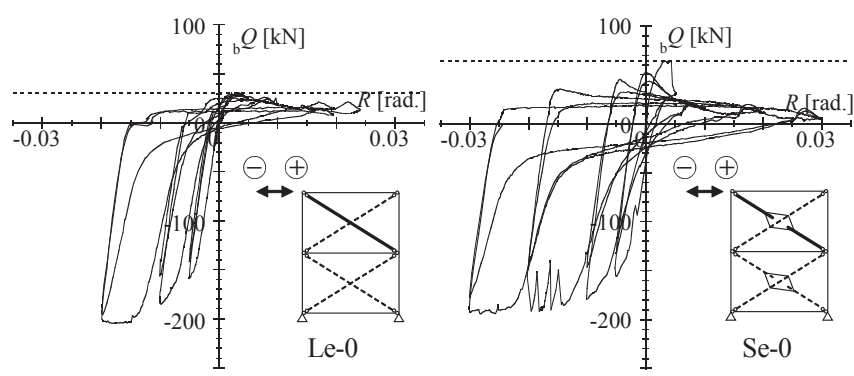

（b）先に圧縮を受けるブレースの負担水平カ
併せて示している，中間ガセットがない場合，座屈長さ $L_{\mathrm{k}}$ は，ブ レース基線とガセットプレートの補剛スチフナとの交点を端部と し, その境界条件をピンとして算出した (図 12). 一方, 中間ガセッ トがある場合, ブレース交差部では引張側ブレースによって面外変 形が拘束されていると考え, 座屈長さ $L_{\mathrm{k}}$ は中間ガセットのない場 合の半分とした. なお, 断面二次半径については構面外方向の軸に 関する $i_{\mathrm{y}}$ を用いた ${ }^{13)}$, 14) なと。実験結果は短期許容圧縮応力度とよく 対応しており, 中間ガセットがある場合の圧縮側最大耐力の上昇は 交差部において面外変形が拘束されているとの仮定で十分に説明で きる.また, 先に述べた圧縮側の変形が進んだ領域において漸近す る耐力は, 座屈後安定耐力 ${ }^{15)}$ として圧縮側最大耐力を 0.4 倍した值 ともほぼ一致する。したがって, 中間ガセットによって引張側と圧 縮側のブレースが連結されている場合には, 圧縮側ブレースは座屈 長さが半分の部材として挙動すると言える.

\section{3 梁端接合部における曲げ負担の影響}

本節では, 梁端接合部におけるボルト径とボルトピッチが全体挙 動に及ぼす影響を考察する。ここではまず, ボルト径とボルトピッ チが異なる Lp-40, Le-0, Lp-80, Se-0 の梁端接合部の履歴挙動を 比較する.梁端接合部における軸方向力一回転角関係, および曲げ モーメントー回転角関係の一例 (2 階梁の右端) を図 13 , 図 14 に示 寸，図中には，表2に示した接合部耐力の計算值を破線で，また全 体挙動の包絡線に対応する履歴を太実線で示している。

梁端接合部に作用寸る軸方向力 (図13)については, 架構全体と同 様のスリップ挙動を伴いながら主に圧縮軸力が作用し, 梁端接合部 がブレースからの応力を圧縮軸力として伝達していることと対応し ている.一方, 梁端接合部に作用する曲げモーメント (図 14) は, い ずれも曲げすべり耐力付近で頭打ちとなり, 新しい变形領域では緩 やかな耐力上昇が見られる。また, 繰り返し変形に対しては, 曲げ すべり耐力程度を維持して安定した履歴挙動を示している. 高力ボ ルト接合部のすべりはボルト孔クリアランスに応じた変形まで生 じ，その間はほぼ一定の耐力を維持する11),16), 17)など. 本実験では新 しい変形領域においてのみブレースからの応力が圧縮軸力として作 用し, この変形領域では梁端接合部の曲げ圧縮側の高力ボルト接合 部が早期に摩擦から支圧へと抵抗機構が移行するため, 耐力上昇が 生じたものと考えられる.

次いで曲げ耐力についてみると, ボルト径が太く, ボルトピッチ が広いほど耐力が上昇していることが分かる.これはボルト径が太 くなることでボルト1本あたりのす心゙り耐力が上昇すること, また ボルトピッチが広くなるとモーメントアームが長くなることから理 解できる. 一方, 回転剛性については, 既往の研究 ${ }^{18)}$ においてピン
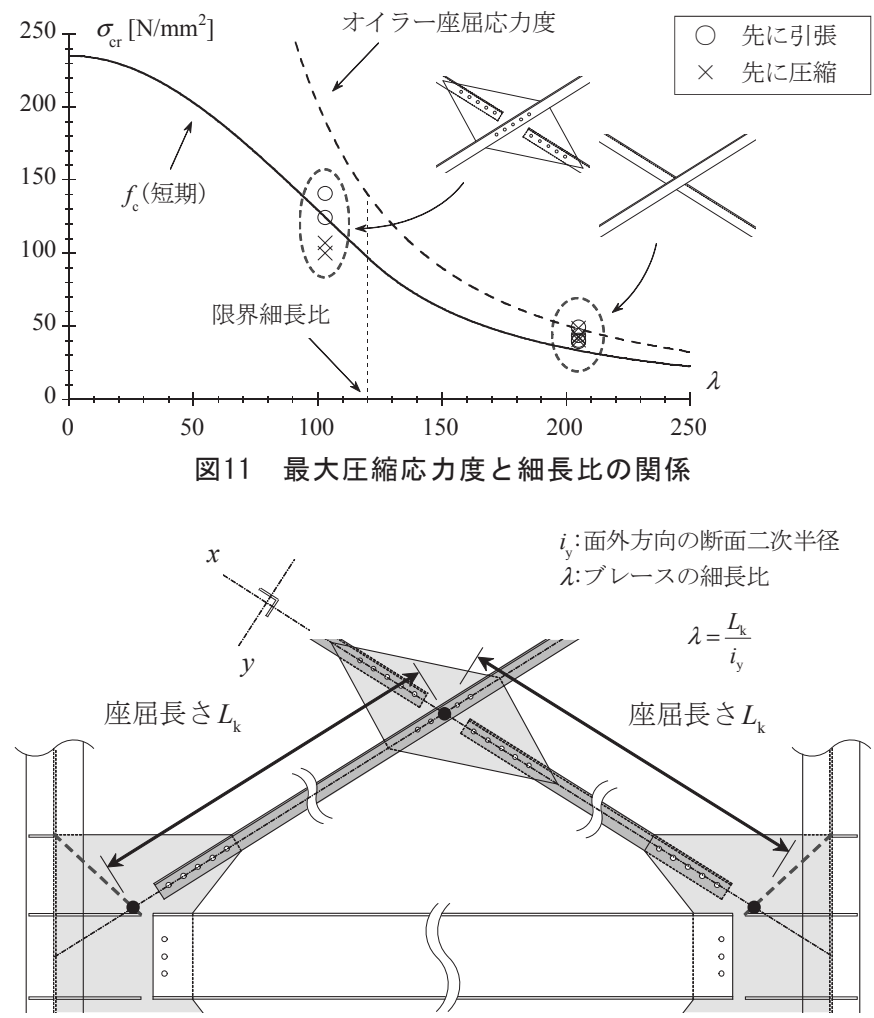

図12 細長比の定義

ディテールの梁端接合部における回転変形がボルト孔周辺の局所変 形により生じるものと仮定して評価を行っている.すなわち, 回転 剛性 $K_{\mathrm{r} 1}$ は, ボルト1本あたりの局所剛性 $k$ とボルトピッチ $p$ を用 いて次式で表される.

$$
K_{\mathrm{r} 1}=k \cdot 2 p^{2} \quad \cdots \cdot(1)
$$

ここでM16@60の回転剛性の実験值を基準として,ボルトピッチ による回転剛性の差を(1) 式に基づき求め, 実験より得られた回転 剛性と比較して図 15 に示寸. なお, 回転剛性 $K_{\mathrm{r} 1}$ は正負の初期サイ クルにおける除荷剛性の平均值として求めた.M16@80の回転剛性 はやや低いが，ボルト径が太いM20@80は，M16を用いた他のボ ルトピッチの回転剛性との差が (1) 式により十分に説明できるもの となっている. 寸なわち, 本実験結果においては, ボルト径の違い が局所剛性, および回転剛性に及ぼす影響は小さいと言える。これ は局所剛性は高力ボルト周辺における摩擦抵抗によってもたらされ るものであり, その抵抗範囲にボルト径の違いが及ぼす影響は小さ いためであると考えられる。

次に曲げす心゙り耐力に達して以降の耐力上昇, 寸なわち二次剛性 


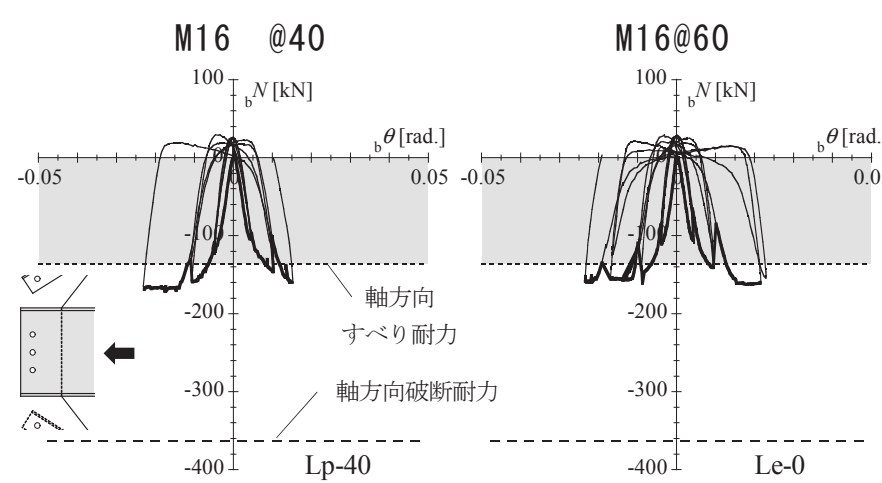

(a) 3-M16, 40mmピッチ

(b) 3-M16, 60mmピッチ

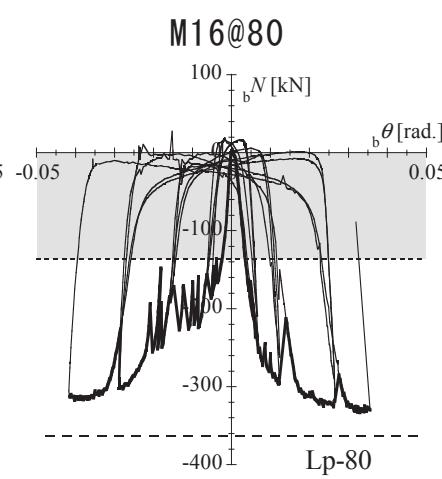

(c) 3-M16, 80mmピッチ

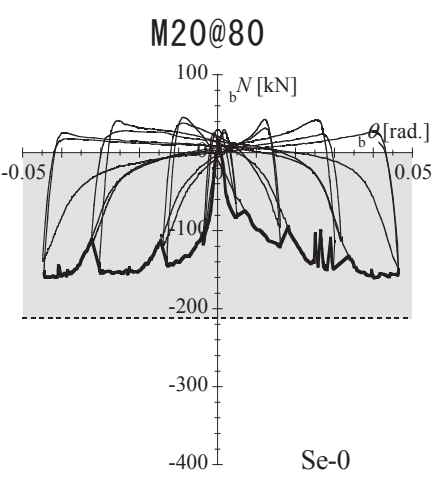

(d) 3-M20, $80 \mathrm{~mm}$ ピッチ

図 13 梁端接合部における軸方向カー回転角関係 (2 階梁の右端)

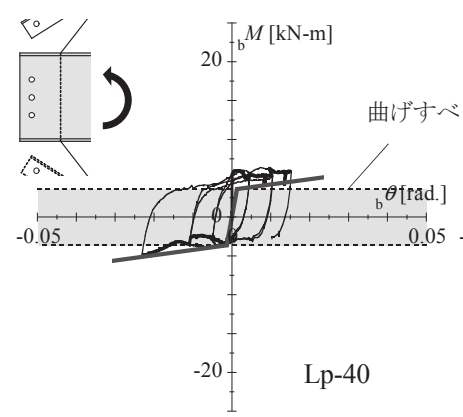

(a) 3-M16, 40mmピッチ

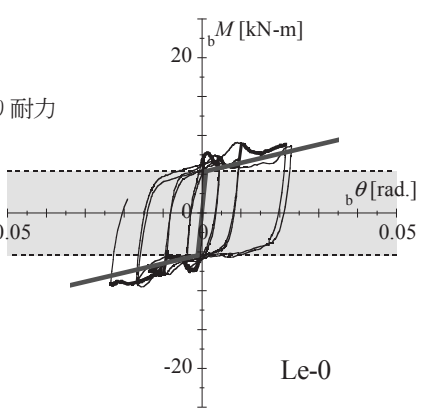

(b) 3-M16, 60mmピッチ

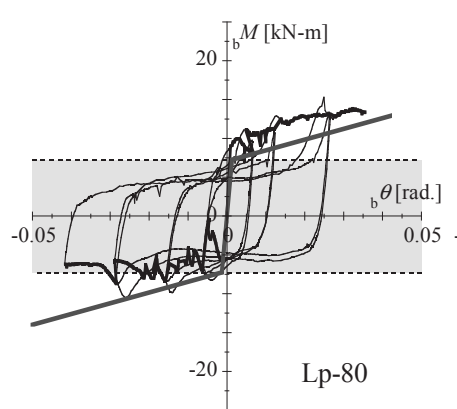

(c) 3-M16, 80mmピッチ

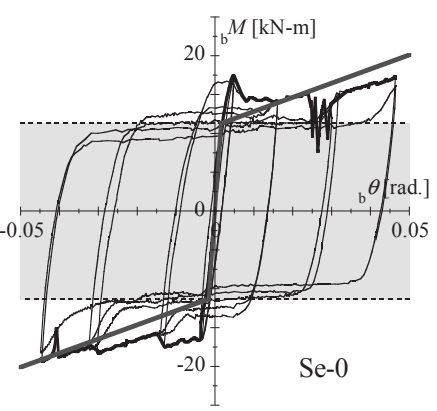

(d) 3-M20, 80mmピッチ

図 14 梁端接合部における曲げモーメントー回転角関係 (2 階梁の右端)

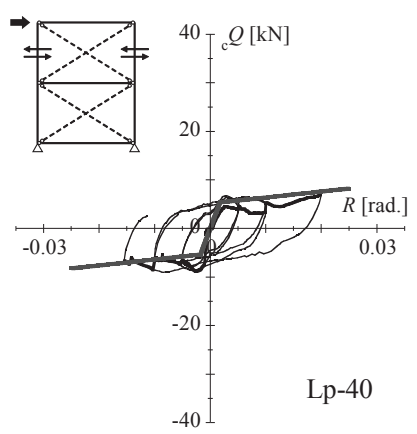

(a) 3-M16, 40mmピッチ

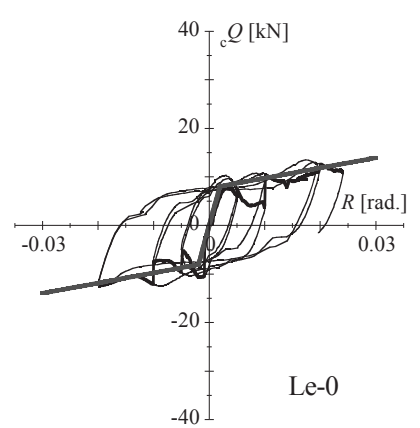

(b) $3-M 16,60 \mathrm{~mm}$ ピッチ

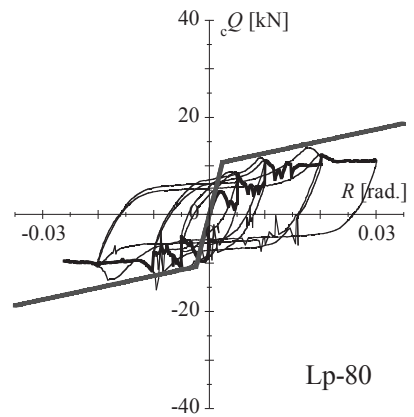

(c) 3-M16, 80mmピッチ

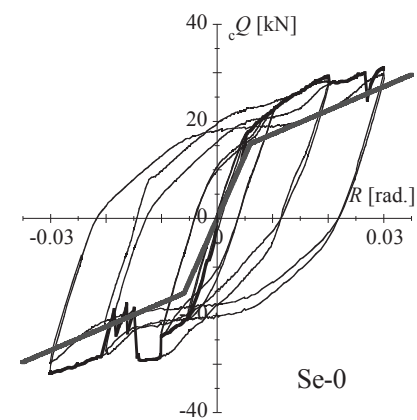

(d) $3-M 20,80 \mathrm{~mm}$ ピッチ

図 16 柱梁架構の負担水平力 (第 2 層)
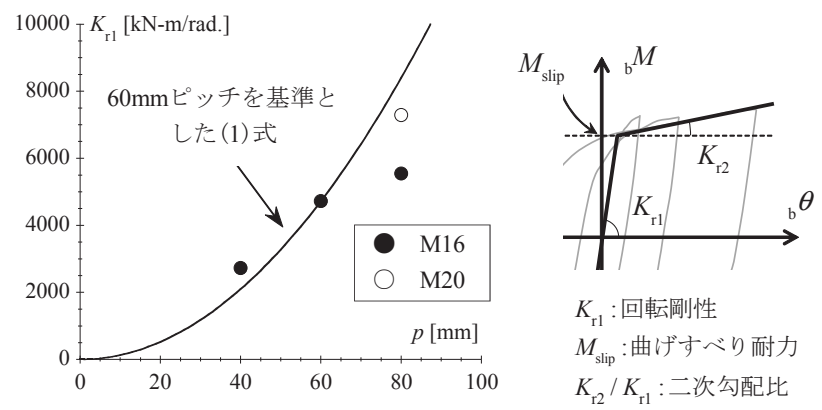

図15 梁端接合部の回転剛性と履歴モデル

$K_{\mathrm{r} 2}$ について検討する.二次剛性についてもボルトピッチが広いほ ど高くなるが，ボルト径の影響も見られる。これは，二次剛性は主 として高力ボルト接合部が支圧抵抗に移行することでもたらされ， 支圧抵抗には高力ボルトの軸部断面積の大きさが影響するためであ ると考えられる。

以上の検討結果より, 梁端接合部の履歴挙動を, 図15に示した回
転剛性を有し, 軸力を考慮していない曲げすべり耐力 (表2)を折れ 曲がり点とするバイリニア型モデルで表す(図14中のグレーの太実 線)。なお，二次剛性についてはM16 では一律に初期回転剛性の $2.5 \%$ とし, M20では軸部断面積の比から $2.5 \%$ の 1.56 倍である $3.9 \%$ としている.ここで, 両側柱のせん断力より求まる柱梁架構の履歴 挙動を図16に示す.また, 梁端接合部のバイリニア型モデルを回転 ばねとして考慮した骨組解析の結果をグレーの太実線として併せて 示して比較する.梁端接合部のボルト径をM16とした試験体(図16 (a)〜 (c)) では, 計算值と実験結果は良く対応している。一方, ボ ルト径M20とした試験体 (図16(d)) についても, 実験の方がやや折 れ曲がり点が高いが, 二次剛性はほぼ一致している。したがって, ピンディテールの梁端接合部の挙動を把握できれば,柱梁架構の挙 動を十分に追跡可能であると言える.

\section{4 ブレースの偏心の影響}

本節では,ブレースの偏心が全体挙動に及ぼす影響について検討 


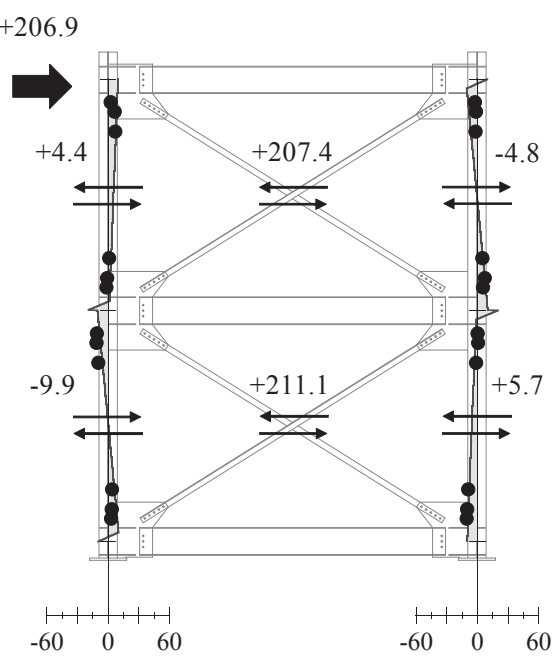

(a) 偏心 $100 \mathrm{~mm}$

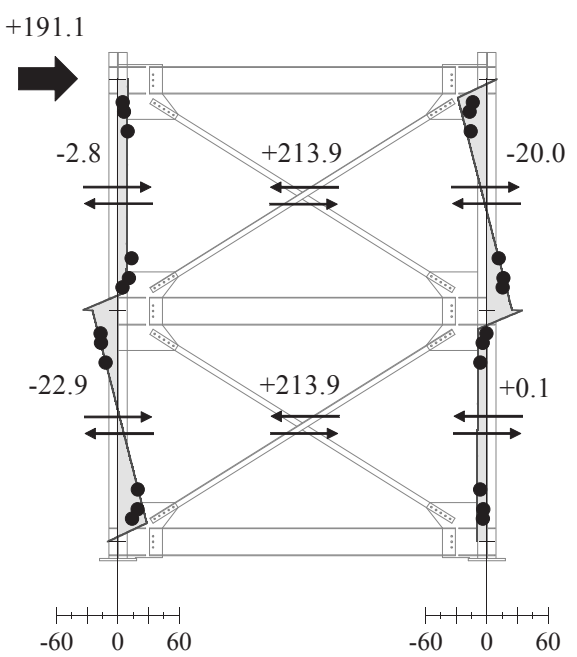

(b) 偏心 $200 \mathrm{~mm}$

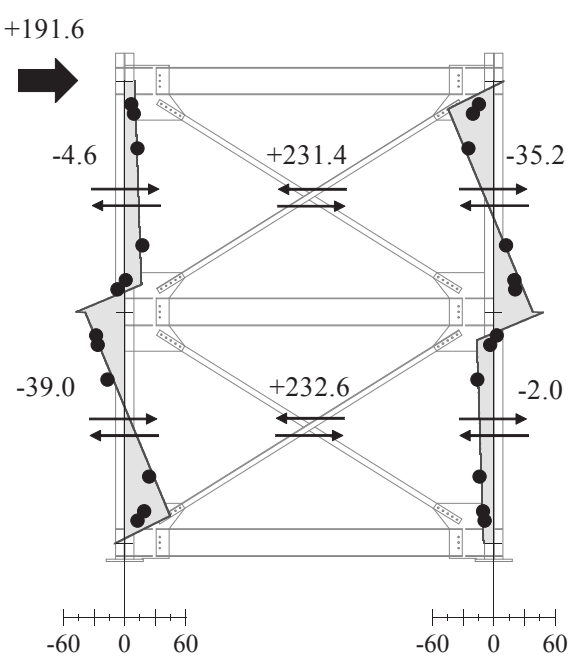

(c) 偏心 $300 \mathrm{~mm}$

図 $17+1 / 50 \mathrm{rad}$. 時の柱の曲げモーメント分布 ( : 実験値, 一 : 評価値)

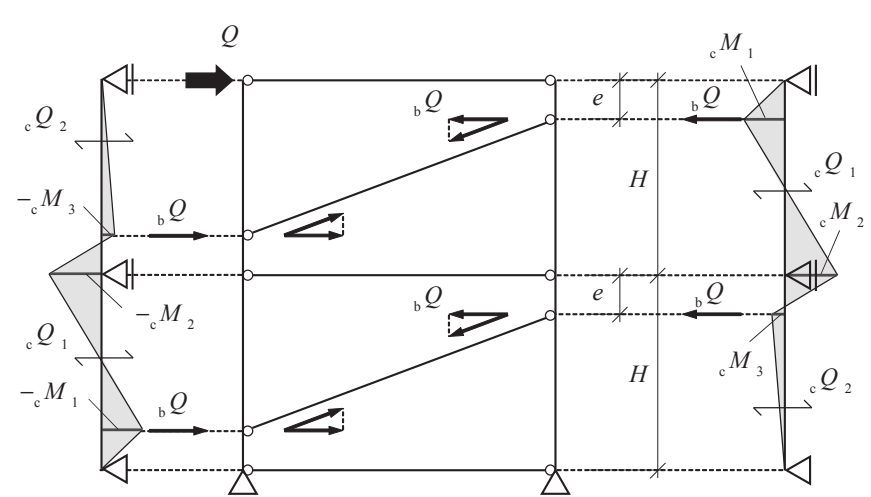

図18 ブレース偏心時の柱の応力分布

する．本実験の試験体は梁端接合部の曲げ抵抗が小さいため，ブ レースの偏心に伴う付加曲げモーメントは主に柱に生じるものと考 えられる.ここでまず,ブレースの偏心に伴う柱の曲げモーメント 分布の変化を考察する.ブレースの偏心距離のみを変化させたLe100, Le-200, Le-300の+1/50rad. 時における柱の曲げモーメント 分布をのプロットにて図17に示す.ブレースの偏心距離が大きくな るにつれて柱に作用する曲げモーメントは増大し, その勾配が反転 していく様子が確認できる.ブレースの偏心距離が大きいLe-200, Le-300では, 柱の負担せん断力は逆せん断状態となっており, 外力 に加担する方向にせん断力が働いている.これは柱断面を小さくし たSeシリーズにおいても同様であった.このようにブレースの偏心 に伴う付加曲げモーメントにより柱の逆せん断状態が引き起こされ たため, 全体挙動 (図 7, 図 8) においてブレースの偏心距離に応じ て水平剛性と最大耐力が低下したものと考えられる.

次にブレースの偏心距離に応じて柱に生じる付加曲げモーメント と逆せん断力の算出方法を検討する. 全体座屈後における圧縮側ブ レースの負担水平力は軸部降伏時の水平耐力と比べて小さい(図10) ことから,ここでは引張側ブレースの負担水平力のみを考える.ま た, 梁端接合部における曲げ負担を無視し, 梁の軸方向の伸縮がな いと仮定すれば, 1本の柱は各階の梁端部をピンもしくはピンロー ラーとする1次不静定構造と考えることができる(図18).さらに各 層における引張側ブレースの負担水平力が等しい状態 $\left({ }_{b} Q\right)$ を考え れば, 各節点における付加曲げモーメントは, 柱の右側が引張とな
る時を正として次式で与えられる.

$$
\begin{array}{ll}
{ }_{\mathrm{c}} M_{1}=-\frac{(H-e)(4 H-3 e)}{4 H^{2}} \cdot{ }_{\mathrm{b}} Q \cdot e & \cdots(2) \\
{ }_{\mathrm{c}} M_{2}=\frac{3(H-e)}{4 H}{ }_{\mathrm{b}} Q \cdot e & \cdots(3) \\
{ }_{\mathrm{c}} M_{3}=-\frac{(H-e)(H+3 e)}{4 H^{2}} \cdot{ }_{\mathrm{b}} Q \cdot e & \cdots \cdot(4)
\end{array}
$$

また，付加曲げモーメントによって各層の柱に生じるせん断力 は, 次式のように求まる.

$$
\begin{aligned}
& \text { c } Q_{1}=-\frac{e(7 H-3 e)}{4 H^{2}}{ }_{\text {ь }} Q \\
& \text { c } Q_{2}=-\frac{e(H+3 e)}{4 H^{2}} \cdot{ }_{\mathrm{b}} Q
\end{aligned}
$$

柱の曲げモーメント分布は, 左右の柱で点対称となるため, 両側 柱のせん断力 ${ }_{\mathrm{c}} Q_{\mathrm{n}}$ は, ${ }_{\mathrm{c}} Q_{1}$ と $Q_{\mathrm{c}}$ の和となる.

$$
\text { c } Q_{\mathrm{n}}={ }_{\mathrm{c}} Q_{1}+{ }_{\mathrm{c}} Q_{2}=-\frac{2 e}{H} \cdot{ }_{\mathrm{b}} Q
$$

以上の仮定から得られた曲げモーメント分布 $((2) \sim(4)$ 式) を実験 結果と比較する.ここで実際の柱の曲げモーメント分布は, 梁端接 合部の曲げ負担を考える必要がある. (2)〜 (4) 式中の 耐力時の水平耐力 ${ }_{b} Q_{\mathrm{y}}$ として求めた曲げモーメント分布と, 3.3 節 より得られる柱梁架構における+1/50 rad. 時の曲げモーメント分布 を単純に足し合わせ, 実線と塗りつぶしで図17中に示す.曲げモー メント分布の計算值は実験結果とよく対応しており,ブレースの偏 心に起因する柱の付加曲げモーメントは柱を1次不静定構造として 得た応力分布により十分に評価できると言える.

\section{5 ブレース架構全体の水平剛性と水平耐力の評価}

最後に, $3.2 \sim 3.4$ 節の検討結果を踏まえ, 架構全体の水平剛性, 水平耐力の評価を行う。まずLeシリーズのブレースの偏心がない Le- 0 と偏心があるLe-200を対象とし, 引張側ブレース, 圧縮側ブ レース, 柱梁架構の負担水平力, および架構全体における層せん断 力を図19に示し, 評価結果との比較を行う.ブレースは, 節点間距 離を材長とした軸部剛性に基づく水平剛性を有し,引張側は軸部降 伏時の水平耐力 ${ }_{\mathrm{b}} Q_{\mathrm{y}}$ を, 圧縮側は座屈後安定耐力に相当する最大圧 

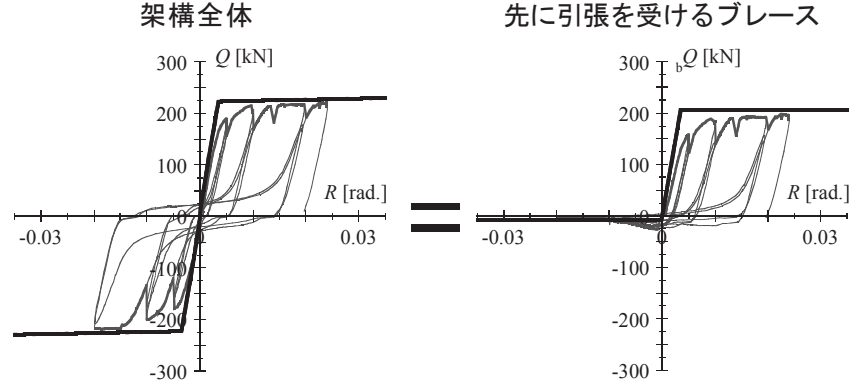

先に圧縮を受けるブレース

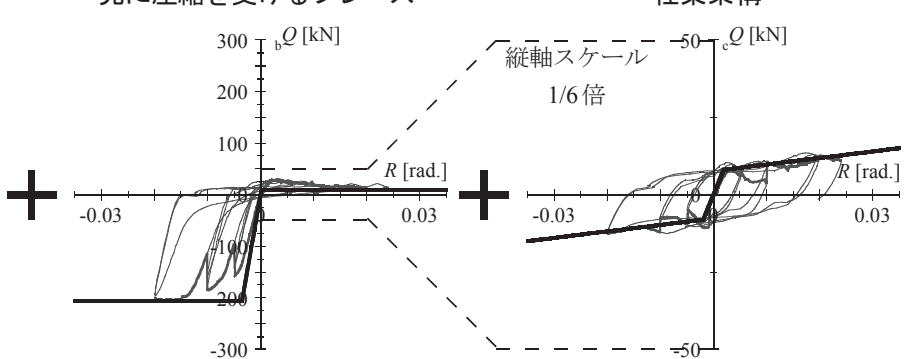

（1）偏心なし(Le-0)
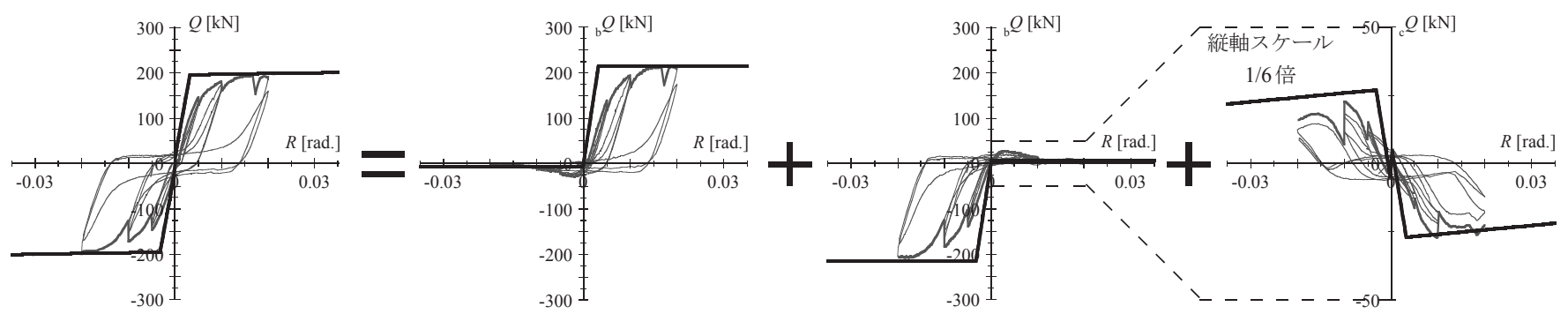

(2) 偏心 $200 \mathrm{~mm}(\mathrm{Le}-200)$

図19 各構造要素の負担水平カと履歴モデル（第2層）

縮耐力の 0.4 倍を折れ点とし, いずれも二次剛性を 0 とした完全弾 塑性型とする. 一方, 柱梁架構は 3.3 節にてバイリニア型にモデル 化した梁端接合部の曲げ負担を基本とし,ブレースの偏心がある場 合には3.4節にて導出した付加曲げモーメントを考慮する. 偏心が ないLe-0では, 前節までの検討に基づく評価結果は, 架構全体を構 成するブレースと柱梁架構のそれぞれの履歴挙動をよく再現できて おり, 全体挙動との対応も良好である。一方, 偏心があるLe-200で は, 水平剛性についてはブレースと柱梁架構のそれぞれとの対応は やや悪くなるが, 負担水平力については柱梁架構におけるブレース の偏心に伴う付加曲げモーメントによる耐力低下をよく反映できて おり, 架構全体の最大耐力との対応も良好である.

さらに, Le, Seシリーズの試験体について, 架構全体の水平剛性 と+1/50 rad. 時の最大耐力をプロットとして表し,ブレースの偏心 距離 $e$ を 1 層分の階高 $H$ で除した偏心率 $e / H$ を横軸にとって図 20, 図 21 に示寸. また, 図の左側には架構全体の計算值における 内訳,つまりブレースと柱梁架構の水平剛性と最大耐力の負担割合 を棒グラフにて表し,ブレースの偏心距離に応じた耐力低下を考慮 した評価結果を破線にて示す.水平剛性については, 評価結果では 柱梁架構の寄与が小さく, 架構全体の水平剛性は引張側ブレースに よって決まっていることが分かる.実験結果は評価結果に対して最 大で $23 \% の$ 誤差があるが,これはブレースの材長を一律に節点間距 離として評価しており，実際には試験体ごとに山形鋼の実長とガ セットプレートの形状が異なることを考慮していないためであると 考えられる.しかしながら, ブレースの偏心距離に応じた水平剛性 の低下はほぼ評価できていることが分かる.一方, 最大耐力につい てみると, 評価結果では圧縮側ブレースの寄与が $9,32 \mathrm{kN}$ 程度, 柱 梁架構の寄与が $12 ， 22 \mathrm{kN}$ 程度となる．Le-300を除く Le シリーズ と Seシリーズの最大耐力の差は, 圧縮側ブレースの負担水平力の差 $(21 \mathrm{kN})$ とほぼ一致しているが, 全体的に実験值は評価結果よりやや 小さめである.これは梁端接合部の曲げ負担とブレースの偏心に伴 う付加応力を独立に扱ったことが原因の一つであると考えられる.
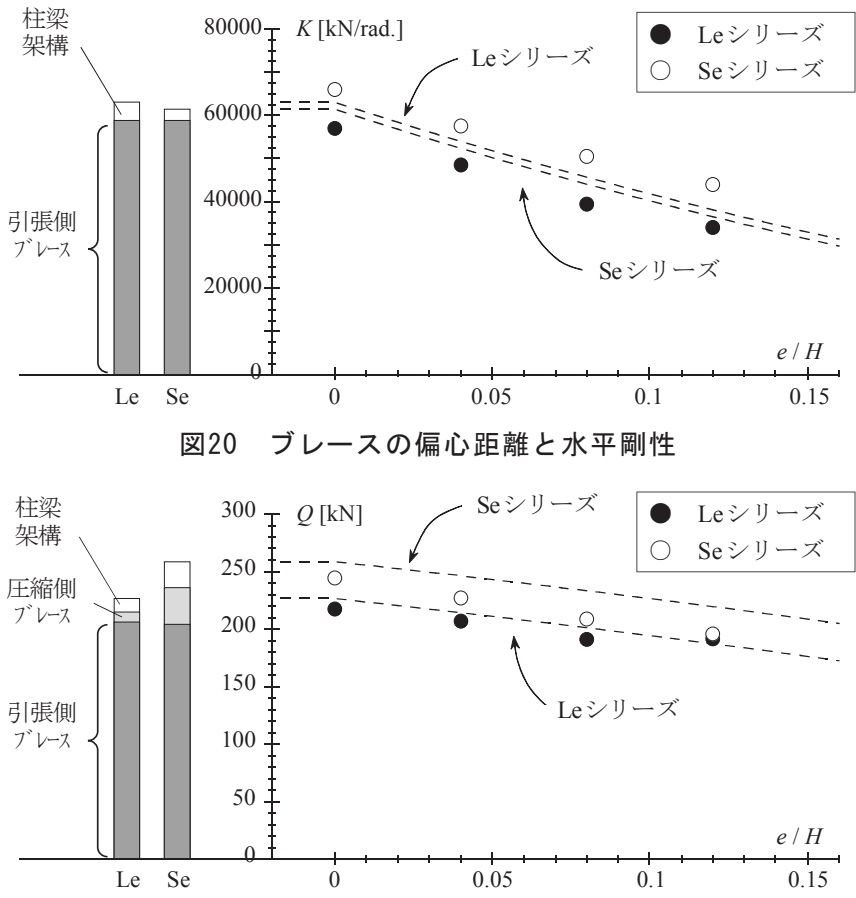

図21 ブレースの偏心距離と最大耐力

しかしながら, 水平剛性と同様, ブレースの偏心距離に応じた最大 耐力の低下はよく対応しており, 少なくともブレースの偏心による 影響は十分に評価可能であると言える。

4. まとめ

本研究では, 2 層 1 スパンの実大ブレース架構実験を行い, 接合 部詳細の違いが架構全体の力学挙動に及ぼす影響について検討し た。以下に得られた結果をまとめる。

[1] 梁端接合部をピンディテールとしたブレース架構では, 梁端接 合部の曲げ負担やブレースの偏心に起因する付加曲げモーメン 卜を含めた柱の応力がほぼ弾性範囲内であれば, 柱に幅厚比の 
大きな断面を使用しても全体挙動にはほとんど影響は見られな かった。

[2] ピンディテールとした梁端接合部は,ブレースの軸部降伏時に 作用するであろう軸方向力に対して保有耐力接合の条件を満た しても, ボルトピッチが広い試験体では高力ボルトの破断に 至った。したがって, 軸力を伝達しながら回転する必要がある 梁端接合部では, 回転変形に伴う付加応力を考慮した設計が必 要であると言える.

[3] X形ブレースの交差部を中間ガセットで連結する場合, 交差部 の面外変形が引張側ブレースにより拘束されるため, 圧縮側ブ レースの座屈長さを半分と仮定した圧縮耐力を発揮することが 分かった.

[4]ブレースの偏心を有するブレース架構では, 偏心距離が大きい ほど柱に生じる付加曲げモーメントが増大するとともに, 柱が 逆せん断状態になることにより, 架構全体の水平剛性と最大耐 力が低下した. また, ブレースの偏心に伴う柱の付加曲げモー メントを, 柱を 1 次不静定構造としてモデル化することにより 評価する方法を示した。

[5] ブレース架構全体の水平剛性と最大耐力は, 圧縮側・引張側ブ レースの負担水平力, 梁端接合部の曲げ負担, およびブレース の偏心による付加応力を考慮することでおおよそ評価できるこ とを示した。

なお, 本論文ではガセットプレートを含むブレースの軸部剛性や ピンディテールの梁端接合部の履歴挙動は実験值に基づいて定めた ため, 梁端接合部の曲げ負担に対する接合部詳細や圧縮軸力の大き さの影響については更なる検討が必要であり, 今後の検討課題であ ると考えている.

\section{謝辞}

本研究は, 平成 25,26 年度 国土交通省 建築基準整備促進事業 「鉄骨造部材の部材種別判定の合理化に関する検討」, および科学研 究費補助金 基盤研究 (C)「損傷に関わる視覚情報に基づいた高部材 の簡易損傷評価法」(研究代表者: 吉敷祥一, 課題番号 : 26420569) による成果です.また, 本実験は当時大阪工業大学の片山紘宜君, 吉原寛真君の卒業論文として実施し, 多くの学生諸氏にご協力いた だきました。ここに記して謝意を表します。

\section{参考文献}

1) 羽倉弘人, 平野道勝, 佐藤 誠, 難波恒夫 : ターンバックル付筋違に関 する研究その $1 \sim 4$, 日本建築学会大会学術講演梗概集, 構造系, pp.485492, 1971.11

2) 田沼吉伸, 加藤 勉, 森田耕次 : 山形鋼筋違接合部の耐力に関寸る研究, 日本建築学会論文報告集, 第 325 号, pp.32-39, 1983.3

3) 加藤 勉, 田中淳夫, 榎本憲正: H形鋼軸組筋かい材端接合部に関する実 験的研究, 日本建築学会大会学術講演梗概集, 構造系, pp.1317-1318, 1983.9/同 その2, 日本建築学会大会学術講演梗概集, 構造系, pp.15551556, 1984.10/同 その3, 日本建築学会大会学術講演梗概集, C 分冊, 構造 II , pp.947-948, 1985.10

4）伊山潤, 山田哲, 松本由香, 吉敷祥一, 小山毅, 島田侑子: 東北地 方太平洋沖地震等による鉄骨造文教施設鉛直ブレースの震動被害, 日本 建築学会技術報告集, 第 19 巻, 第 41 号, pp.147-152, 2013.2

5）難波恒夫, 高橋雅充: ターンバックル付きブレースを有する鉄骨フレー 么実験, 日本建築学会大会学術講演梗概集, 構造系, pp.1417-1418,
1978.9

6) 加藤 勉, 森田耕次, 田沼吉伸, 高橋良明 : 筋違付骨組の挙動に与える 筋違接合部の影響に関する実験的研究, 日本建築学会大会学術講演梗概 集, 構造系, pp.1293-1294, 1980.9

7）尾澤 聡，小澤亮公，山下哲郎：山形鋼を用いたX型ブレースの耐震性 能に関する実験的研究 その $1 \sim 2$, 日本建築学会大会学術講演梗概集, C-1 分冊, 構造 III, pp.801-804, 2009.8

8）吉敷祥一, 近藤直弥, 山田哲, 長谷川隆: 接合部詳細の違いに着目し た引張ブレース付き柱梁部分架構の実験, 日本建築学会構造系論文集, 第 80 巻, 第 711 号, pp.779-788, 2015.5

9) 建築物の構造関係技術基準解説書編集委員会: 2015 年版 建築物の構造 関係技術基準解説書, pp.600-602, 2015.6

10）日本建築学会 : 鋼構造設計基準一許容応力度設計法一, 第 4 版, 2005.9

11）日本建築学会：鋼構造接合部設計指針，第3 版, 2012.3

12）巽 信彦, 吉敷祥一, 山田哲, 長谷川隆: 引張ブレース構造における梁 端ピンディテール接合部の力学挙動, 鋼構造年次論文報告集, 第22巻, pp.5-12, 2014.11

13）増田真也, 山下哲郎: 両端ガセットプレート接合された山形鋼ブレース の座屈耐力に関する実験, 日本建築学会大会学術講演梗概集, C-1分冊, 構造 III, pp.979-980, 2010.9

14）吉敷祥一, 巽 信彦: 単一山形鋼ブレースの残留たわみと両脚の開きに 基づく損傷評価 - “見える損傷” の定量化に基づく鋼構造骨組の即時 損傷評価法 その $2-$, 日本建築学会構造系論文集, 第 81 巻, 第 719 号, pp.143-153, 2016.1

15）日本建築学会: 鋼構造限界状態設計指針・同解説, 第3 版, pp.134-145, 2010.2

16）佐藤篤司, 小野徹郎: 偏心荷重を受けるボルト接合部のモデル化, 日本 建築学会大会学術講演梗概集, C-1 分冊, 構造III, pp.1039-1040, 2008.9

17）佐藤篤司, 吹田啓一郎, 多田裕一: 支圧を考慮した高力ボルト接合部の 最大耐力評価, 日本建築学会構造系論文集, 第76巻, 第662号, pp.845$853,2011.4$

18）西本信哉, 安田 聡, 成原弘之, 関 清豪, 佐藤英佑 : 鉄骨小梁端高力ボ ルト接合部の回転剛性とすべり耐力その1 実験概要, 日本建築学会大 会学術講演梗概集, C-1 分冊, 構造III, pp.703-704, 2010.9 


\title{
EXPERIMENTAL STUDY ON 2 STORY-1 BAY FULL-SCALE BRACED FRAME FOCUSING ON THE DIFFERENCE OF CONNECTION DETAIL
}

\author{
Nobuhiko TATSUMI*, Shoichi KISHIKI**, Takashi HASEGAWA*** \\ and Satoshi YAMADA*** \\ * JSPS Research Fellow, M.Eng. \\ (Grad. Stud., Osaka Institute of Technology) \\ ** Assoc. Prof., F.I.R.S.T., Tokyo Institute of Technology, Dr.Eng. \\ *** Senior Researcher, Structural Engineering Dept., Building Research Institute, Dr.Eng. \\ **** Prof., F.I.R.S.T., Tokyo Institute of Technology, Dr.Eng.
}

Braced frame structures are used for school gymnasiums and factories with large space. These are very important buildings which will be used as emergency public shelters in time of disaster. In braced frames, generally the columns are placed along their weak axis for wide-flange steel cross sections and the beam web is connected through gusset plates on the column web by using high strength bolts. These beam-to-column connections are assumed as a pin connection at the stage of seismic design, and seismic performance of the braced frames depend on the strength of the brace. Connection of these components is made based on general design practice although its shape is very complex. In other words, the effect of various differences in connection details on the seismic performance of the braced frame is unclear at the stage of seismic design.

This paper focuses on differences in connection details, and describes their effects on structural behaviors of braced frame structures. The cyclic loading tests of 2 story-1 bay full-scale braced frames with various connections were carried out. The main parameters are: presence of gusset plate at intersection of braces, details at beam-end connection, and a connection eccentricity of brace. Gusset plate at intersection of braces is prepared to investigate the effect on strength of compression brace. Details at beam-end connection are adopted for the purpose of verifying the influence on the seismic performance of braced frames. Connection eccentricity of brace is selected in order to investigate the additional stress on the framing components.

The test results can be summarized as follows: (1) presence of gusset plate at intersection of braces results in decrease in effective length of buckling; (2) connection detail with wide pitch or large diameter of bolts caused larger lateral force of beam-column subassemblies; (3) connection eccentricity of brace led to decrease in maximum strength and elastic stiffness of the braced frame. 